\title{
Impact of television advertising on human health*
}

\section{Wpływ reklamy telewizyjnej na zdrowie czlowieka*}

\section{Maciej Rogala1, Pawel Kawalec ${ }^{2}$, Ewa Donesch-Jeżo ${ }^{3}$}

\author{
${ }^{1}$ Zakład Polityki Zdrowotnej i Zarzq̨dzania, Instyłut Zdrowia Publicznego, Wydział Nauk o Zdrowiu, Uniwersytet Jagielloński Collegium \\ Medicum, Kraków, Polska \\ Department of Health Policy and Management, Institute of Public Health, Faculty of Health Sciences, Jagiellonian University Medical College, \\ Cracow, Poland \\ Head: prof. dr hab. C.W. Włodarczyk
}

${ }^{2}$ Zakład Gospodarki Lekiem, Instyłut Zdrowia Publicznego, Wydział Nauk o Zdrowiu, Uniwersytet Jagielloński-Collegium Medicum, Kraków, Polska

Department of Drug Economics, Institute of Public Health, Faculty of Health Sciences, Jagiellonian University Medical College, Cracow, Poland Head: prof. dr hab. A. Pilc

${ }^{3}$ Wydział Psychologii i Nauk Humanistycznych, Krakowska Akademia im. Andrzeja Frycza Modrzewskiego, Kraków, Polska Faculty of Psychology and Humanities, Andrzej Frycz Modrzewski Krakow University, Cracow, Poland Head: dr hab. L. Pawłowski, prof. UJ

\section{Abstract}

The aim of the review was to assess the impact of the mass media, especially television, on human health effect. A systematic review of the literature was performed using Medline (accessed through PubMed) as well as the Google Scholar for the period till December 2015. Reports in sources other than the medical information database have also been examined, and the literature included in the identified scientific reports has been hand-searched. The study analyzed the main areas which previously investigated the relationship between advertising and physical activity, smoking, nutrition and diet, as well as the impact of such transfers on the market of drugs and health promotion. The results of the research allowed drawing the conclusion that advertising

\section{KEYWORDS:}

advertising, health effect, Health Impact Assessment (HIA), direct-to-consumer (DTC), drugs, sale, prescription, health, health promotion, smoking, physical activity, food, obesity

\section{Streszczenie}

Celem przeprowadzonego przegladu badań $i$ zawartych $w$ artykule analiz byta ocena wplywu massmediów, w szczególności telewizji, na obszar ludzkiego zdrowia. Systematyczny przeglad literatury zostal przeprowadzony przy użciu bazy danych MEDLINE (dostęp poprzez PubMed), jak również Google Scholar $w$ okresie do grudnia 2015 r. Sprawdzono również raporty ze źródet innych niż medyczne bazy danych oraz piśmiennictwo zawarte $w$ zidentyfikowanych doniesieniach naukowych. Analizie poddano również główne obszary, które wcześniej były przedmiotem studiów $w$ zakresie relacji pomiędzy reklama a aktywnościa fizyczna, paleniem, żywieniem $i$ dieta, jak również wplyw tego przekazu na rynek leków oraz promocje zdrowia. Rezultaty przegladu i analiz daty

\footnotetext{
* In the article there was fragmentary included an issue corresponding to subject of research of application in Poland methodology of the Health Impact Assessment (HIA) - in project "Limitation of social inequalities in health", Programme PL 13 co-financed from Norway Grants 20092014 - in the consortium "Science and Health (agreement no. A-AE-KN-12/5/2013)

* W artykule uwzględniono w sposób wycinkowy problematykę nawiązującą do obszaru badania perspektyw zastosowania w Polsce metodologii Oceny Skutku Zdrowotnego (Health Impact Assessment, HIA) - w ramach projektu „Ograniczanie społecznych nierówności w zdrowiu", Programu PL 13 współfinansowanego ze środków Norweskiego Mechanizmu Finansowego 2009-2014 - w ramach konsorcjum „Nauka i Zdrowie (umowa nr A-AE-KN-12/5/2013).
}

\section{HAStA INDEKSOWE:}

reklama, skutek zdrowotny, ocena wpływu na zdrowie, leki, sprzedaż, recepty, zdrowie, promocja zdrowia, palenie, aktywność fizyczna, jedzenie, otyłość 
has a significant impact on the demand and sales of drugs. Television commercials encouraging smoking cessation could also be associated with a significant public response. The review also demonstrated the positive effect of interventions involving media, which resulted in an increase in knowledge and awareness about the role of physical activity in the area of human health. Television advertising influences food preferences, consumption patterns, and is one of the main factors reducing the unhealthy diet and over-consumption in children, as well as bad eating habits with food rich in fat, salt and sugar. Results of the studies also showed that advertising could have a negative impact on health effect since some food promotion generates anorexia or obesity. Referring to the examples of media campaign involving television that are presented in this article, it must be stressed that advertising can change attitudes or behaviour. Both commercial advertising as well as social activities could influence recipients by persuasion. podstawy do konkluzji, iż reklama ma olbrzymi wptyw na popyt $i$ sprzedaz leków. Przeglad badań pozwolit na zidentyfikowanie zależności, iż reklama telewizyjna zachęcająca do rzucenia palenia papierosów wiąze się z istotna odpowiedzia spoleczeństwa. Analizy pokazaty równiez pozytywny efekt interwencji przy użyciu mediów skutkujący wzrostem wiedzy i świadomości na temat roli wptywu kultury fizycznej na ludzkie zdrowie. Wyniki badań wykazaty, iż telewizyjna reklama ma również wpływ na preferencje żywieniowe, wzory konsumpcji i jest jednym z głównych czynników redukujacych niezdrowa diete $i$ nadkonsumpcje u dzieci, jak również złe nawyki żywieniowe zwiąane $z$ duża ilościa tluszczu, soli i cukru. Rezultaty tych badań pokazaty również, iż reklama może mieć negatywny wplyw na ludzkie zdrowie, a niektóre materiały promocyjne zwiąane z żywnościa, poprzez swoje oddziatywanie, generuja $w$ efekcie anoreksje lub nadwage. Odnoszac się do prezentowanych w tym artykule przyktadów telewizyjnych kampanii medialnych należy podkreślić, iż reklama może zmieniać postawy lub zachowania. Należy dodać, iż zarówno reklama komercyjna, jak i społeczna może oddziatywać na jej odbiorców poprzez swoje środki perswazji.

\section{Wprowadzenie i cel pracy}

W artykule podjęto problem wpływu oddziaływania mass-mediów, w tym szczególnie telewizji, na zdrowie człowieka. Przeprowadzone dotąd badania dowodzą bowiem istnienia zależności pomiędzy oglądaniem reklamy emitowanej w telewizji a jej wpływem na ludzkie zdrowie. $Z$ uwagi na opiniotwórczą siłę reklamy wynikającą z wszechobecności oraz towarzyszących jej środków przekazu przyjęto, iż może być ona czynnikiem mającym doniosłe znaczenie dla postaw i zachowań człowieka o charakterze pro- i anty-zdrowotnym. Uznano, iż systematyczny przegląd literatury naukowej, analiz i raportów pozwoli na szczegółową analizę czynników oddziaływania reklamy telewizyjnej i tym samym da odpowiedź, co powoduje, że ten rodzaj przekazu może mieć związek ze skutkiem zdrowotnym u dzieci, młodzieży czy dorosłych.

Systematyczny przegląd literatury w obszarze oddziaływania środków masowego przekazu za pomocą reklamy na zdrowie - w tym ze szczególnym uwzględnieniem reklamy telewizyjnej 
using Medline (accessed through PubMed) for the period till December 2015, according to the guidelines in Cochrane Handbook for Systematic Reviews of Interventions. ${ }^{1}$ Additionally, the resources of the Google Scholar have been searched. Searching strategy complied with the index of MeSH (Medical Subject Headings) synonyms and was carried out with the use of Boole's logical operators. Reports in sources other than the medical information database, such as registers of clinical examinations, were also checked. Moreover, identified scientific reports (e.g. systematic reviews) were searched to find the literature relevant to the assumptions of this study. The analysis included both controlled and uncontrolled randomized clinical trials, prospective pilot trials, observations, meta-analyses, as well as systematic reviews published in the Polish and English languages which assessed the impact of advertising on the demand and sale of medicines, and healthcare attitudes of the population. The analysis encompassed the trials independent of the status and date of publication. The search resulted in identification of tens of reports pertaining to the analyzed problem. The following keywords were used: advertising, direct-to-consumer (DTC), drugs, sale, prescription, health, health effect, health promotion, smoking, physical activity, food, obesity when using Medline, and advertising, drugs, sale, prescriptions, health, health effect, health promotion, smoking, physical activity, food, obesity when the Google search engine was used. To deepen the analysis of the problem of the impact of television advertising on health, we also presented examples of reports, projects and the socalled good practices in the area of the influence and quality of television advertising in the context of human health.

In order to achieve the main objective of this research, that is, the analysis of the relationship between television commercials and health, the research question was raised: what determines the influence of television advertising on people and, as a result, on their health? The analysis covered the main areas in which until now the relationship has been studied between advertisement content and physical activity, cigarette smoking, eating
- przeprowadzono z wykorzystaniem bazy danych MEDLINE (dostęp przez PubMed) za okres do grudnia 2015 roku, zgodnie z wytycznymi Cochrane Handbook for Systematic Reviews of Interventions. ${ }^{1}$ Dodatkowo przeszukano zasoby Google Scholar. Strategia wyszukiwania została przeprowadzona zgodnie z indeksami synonimów MeSH (Medical Subject Headings) oraz z wykorzystaniem operatorów logicznych Boole'a. Sprawdzono również doniesienia w źródłach innych niż bazy informacji medycznej - rejestry badań klinicznych, a także przeszukano piśmiennictwo zawarte $\mathrm{w}$ zidentyfikowanych doniesieniach naukowych (np. w przeprowadzonych przeglądach systematycznych) w celu odnalezienia literatury odpowiadającej założeniom tego opracowania. Analiza obejmowała zarówno kontrolowane próby kliniczne z randomizacją, jak również badania bez randomizacji, prospektywne badania pilotażowe, badania obserwacyjne, metaanalizy i przeglądy systematyczne opublikowane w języku angielskim i polskim, dotyczące oceny wpływu reklamy na popyt i sprzedaż leków oraz postaw zdrowotnych populacji. Do analizy włączono badania niezależnie od statusu i daty publikacji. W wyniku wyszukiwania zidentyfikowano kilkadziesiąt opracowań dotyczących analizowanego problemu. Użyto następujących słów kluczowych: advertising, direct-to-consumer, DTC, drugs, sale, prescription, health, health effect, health promotion, smoking, physical activity, food, obesity w przypadku Medline oraz reklama, leki, sprzedaż, recepty, zdrowie, skutek zdrowotny promocja zdrowia, palenie aktywność fizyczna, jedzenie, otyłość przy przeszukaniu wyszukiwarki Google.

W celu pogłębienia problematyki oddziaływania reklamy telewizyjnej na zdrowie w opracowaniu przedstawiono również przykłady opracowań, przedsięwzięć oraz tzw. dobrych praktyk w zakresie wpływu i jakości reklamowego przekazu telewizyjnego w kontekście ludzkiego zdrowia.

Dla realizacji głównego celu badawczego tego opracowania, czyli analizy obszaru zależności pomiędzy reklamą telewizyjną a zdrowiem postawiono podstawowe pytanie badawcze, co decyduje, że reklama telewizyjna może mieć wpływ na ludzi i w efekcie na ich zdrowie. W opracowaniu 
habits and diet, as well as the influence of this mass medium on the drug market and health promotion.

\section{Impact of advertising on the sale of drugs}

The first of the topics discussed referred to the impact of advertising on the demand and sale of drugs, the effect of which can significantly influence health, both in a positive and negative way. The identified research concerned mainly American and Australian experience in the area of television advertising of prescription drugs.

Results of these investigations allowed ascertaining that advertising has substantial impact on drug demand and sale. ${ }^{2-8}$ The identified investigations showed that drug advertising influences both the doctor and the patient. Drug advertisements were classified into two groups: those presenting a specific medicinal preparation and those presenting specific disease. The selected studies demonstrated that the advertisement showing a particular disease caused increased prescribing of the drugs used in the treatment of this disease, as well as an increased number of diagnosed cases of this disease. , $^{2,3,6}$ Similarly, advertisements presenting a specific medicinal product caused significantly increased demand for this pharmaceutical product. Moreover, the tendency to prescribe the advertised drug by doctors has also been observed. ${ }^{4,6}$ Interestingly, patients often ask the doctor to prescribe the drug which they have seen advertised. ${ }^{5,7}$ Advertisements also have a strong influence on the attitudes of patients because after seeing an advertisement dealing with a particular disease, patients start to think about their own health and visit the doctor, which is associated with a greater number of diagnosed cases of this disease. ${ }^{2,3,6}$ One of the analysed investigations revealed that an advertised drug generates an income of about $\$ 22$ million for the pharmaceutical company that produced that drug. ${ }^{8}$ It should be noted that the most frequently advertised drugs are the new and expensive ones, reducing, in this way, the sale of medicines which for a long time have been on the market and are much cheaper than the new ones. One of the studies concluded that the doctors were more inclined to poddano analizie główne obszary, w jakich dotychczas badano zależności pomiędzy treściami reklam a aktywnością fizyczną, paleniem papierosów, sposobem odżywianiem się a dietą, jak również wpływem tych przekazów na rynek leków oraz promocję zdrowia.

\section{Wplyw reklamy na sprzedaż leków}

Pierwszy z poruszonych tematów dotyczył wpływu reklamy na popyt i sprzedaż leków, których skutki mogą mieć znaczący wpływ na zdrowie, zarówno pozytywny, jak i negatywny. Zidentyfikowane badania dotyczyły w większości doświadczeń amerykańskich i australijskich odnośnie reklamy telewizyjnej leków przepisywanych na receptę.

Wyniki tych badań pozwoliły na stwierdzenie, że reklama ma istotny wpływ na popyt sprzedaż leków. ${ }^{2-8} \mathrm{~W}$ zidentyfikowanych badaniach wykazano, że reklama leków wpływa zarówno na lekarza, jak i pacjenta. Reklamy leków zostały podzielone na dwie grupy: I przedstawia konkretny preparat leczniczy, II konkretną jednostkę chorobową. W wyniku przeglądu zidentyfikowano badania, które wykazały, że reklama w której ukazana jest konkretna jednostka chorobowa, wiąże się z zwiększeniem preskrypcji leków związanych z tą chorobą, a także z większą liczbą zdiagnozowanych przypadków danej choroby. ${ }^{2,3,6} \mathrm{Z}$ drugiej strony, zaobserwowano istotnie zwiększony popyt na farmaceutyki w przypadku reklam przedstawiających konkretny produkt. Zauważono również tendencję do przepisywania przez lekarzy recept na produkt reklamowany. ${ }^{4,6}$ Istotny jest również fakt, że to często pacjenci proszą lekarza o lek, który widzieli w reklamie. ${ }^{5,7}$ Reklamy mają także silny wpływ na postawę pacjentów, ponieważ po obejrzeniu przekazu reklamowego dotyczącego konkretnej choroby, pacjenci zastanawiają się nad własnym stanem zdrowia i później zgłaszają do lekarza, co jednocześnie wiąże się z większą liczbą zdiagnozowanych przypadków choroby. ${ }^{2,3,6} \mathrm{~W}$ jednym $\mathrm{z}$ badań przedstawiono ciekawą zależność, otóż reklama leku generuje około 22 mln dolarów dochodów dla firmy farmaceutycznej w przeliczeniu na reklamowany lek. ${ }^{8}$ Należy również zwrócić uwagę na to, że leki najczęściej rekla- 
diagnose depression among those patients who asked for an advertised medication. ${ }^{4}$

\section{Advertising and cigarette smoking}

Due to the global increase in the number of smokers, and negative health effects of smoking, the World Health Organization (WHO) recommended that every country should implement a multi-component, comprehensive approach to smoking. ${ }^{9}$ Since television advertising is recognized as one of the most effective means of conveying information, many campaigns against tobacco smoking are transmitted to the public in this way. A number of studies have been identified which confirm high effectiveness of this way of information submission to intensify smoking cessation by the society. Commercials are effective not only in discouraging smoking, but also in its promotion. One of the studies revealed that adolescents exposed to cigarette advertising are more likely to start smoking and get addicted to it than those who do not watch this type of advertising. ${ }^{10}$

The survey identified the studies revealing that $\mathrm{TV}$ advertising that encourages smoking cessation results in significant public response. ${ }^{9-11,14}$ It has been shown that increased frequency of antismoking advertising campaigns substantially increases the number of attempts to give up smoking. ${ }^{9}$ The commercials in which socially recognizable people and celebrities stop smoking proved highly effective, since such television spots are more successful in drawing attention of smokers, and are better remembered by them. One of the studies demonstrated that the commercials with star celebrities were noticed by $88 \%$ of smokers, and $45 \%$ of them could even cite the name or description of one of the advertised products. ${ }^{10}$ Moreover, the research indicates that advertising can strengthen both short- and long-term abstinence. ${ }^{10}$ Commercials that show emotional and personal experience, ${ }^{11}$ those that show negative consequences of bad habits such as cigarette smoking, ${ }^{12,14}$ and humorous ones $^{12,14}$ generate the highest efficacy. One of the studies revealed that the application of humour to advertising can be more effective in conveying mowane są nowe i drogie, przez co spada sprzedaż leków, które od dłuższego czasu znajdują się na rynku i są dużo tańsze od nowo wprowadzonych na rynek. Ciekawym wnioskiem z innego badania było również stwierdzenie, że lekarze byli bardziej skłonni zdiagnozować depresję wśród pacjentów, którzy poprosili o reklamowany lek. ${ }^{4}$

\section{Reklama a palenie papierosów}

Po globalnym wzroście liczby palaczy oraz negatywnych skutkach zdrowotnych związanych z paleniem tytoniu, WHO (Światowa Organizacja Zdrowia, ang. World Health Organization) zaleciło, aby wszystkie kraje wdrożyły wieloskładnikowe, kompleksowe podejście do palenia. ${ }^{9}$ Jako jeden z najskuteczniejszych sposobów przekazywania informacji uznaje się reklamę telewizyjną, dlatego wiele kampanii przeciwko paleniu tytoniu przekazywanych jest opinii publicznej właśnie w ten sposób. Zidentyfikowano badania, które potwierdzają wysoką skuteczność tej drogi przeka$\mathrm{zu}$ w zintensyfikowaniu rzucania palenia przez społeczeństwo. Reklama jest skuteczna nie tylko $\mathrm{w}$ zniechęcaniu do palenia tytoniu, ale również $\mathrm{w}$ jego promowaniu. W jednym $\mathrm{z}$ badań wykazano, że młodzież narażona na reklamy papierosów jest bardziej skłonna do rozpoczęcia palenia czy wejścia w nałóg. ${ }^{10}$

W wyniku przeglądu zidentyfikowano badania, w których reklama telewizyjna zachęcająca do rzucenia palenia wiąże się $\mathrm{z}$ istotną odpowiedzią społeczeństwa.9-11,14 Wykazano, iż zwiększenie częstotliwości reklam antynikotynowych, wiąże się z istotnym wzrostem prób rzucenia nałogu przez palaczy. ${ }^{9}$ Wysoką skutecznością wykazują się również reklamy, w których rozpoznawalni społecznie i sławni ludzie rzucają palenie; takie spoty znacznie lepiej zwracają uwagę palaczy oraz są dobrze przez nich zapamiętywane. W jednym $\mathrm{z}$ badań udowodniono, że reklama z udziałem znanych osób została zauważona przez $88 \%$ palaczy, natomiast $45 \%$ może nawet przytoczyć z pamięci nazwę lub opis jednego z elementów kampanii. ${ }^{10}$ Wyniki badań wskazują również, że reklama może wzmocnić zarówno krótko-, jak i długoterminową abstynencję. ${ }^{10}$ Najwyższą skutecznością wykazały się reklamy zawierające emocjonalne i osobi- 
the message by acting in three different ways: by improving the mood of the viewers, by attracting their attention and helping them to understand the message, and by increasing a positive attitude to the advertisement. ${ }^{14}$

\section{Relationship between advertising and physical activity}

Referring to various scientific studies identified in the review, we should primarily distinguish the results of the investigations carried out in Australia, Scotland, Canada and the USA concerning the effectiveness of media campaigns (national and state), particularly television advertising, to encourage the intensification of physical activity among adults and children. They showed a positive role of intervention with the use of mass media, which resulted in the increased knowledge and awareness of the effect of physical culture on health. However, it does not always mean a radical change of attitudes and behaviours in this area, or the change, if it occurred, was frequently shortterm. ${ }^{15-27}$

The research has also demonstrated that the commercials propagating slimness of body in persons who exercise have a significant impact primarily on women. Also, commercials presenting physical exercises proved to be highly effective in changing behaviours and attitudes towards physical activity. ${ }^{28} \mathrm{~A}$ major issue nowadays is low physical activity among children. The research into this problem demonstrates that commercials showing negative effects of obesity in children, and the role of physical activity in reducing this phenomenon, have strong impact on mothers. They frequently agree that the lack of physical activity in children is a serious problem, however, not all mothers notice this problem in their own children. ${ }^{29}$ An extensive study done in Australia is worth noting since it shows how TV advertising was used to promote physical activity in the society, causing noticeable increase in awareness and behaviour change. ${ }^{30}$

\section{Impact of advertising on eating habits and the emergence of diseases}

This review also focused on studies of the relationship between watching television ste doświadczenia ${ }^{11}$ oraz reklamy, które ukazują negatywne skutki palenia tytoniu. ${ }^{12,14}$ Ciekawym wnioskiem może być również wysoka skuteczność reklam pełnych humoru. ${ }^{12,14} \mathrm{~W}$ wyniku jednego $\mathrm{z}$ analizowanych badań stwierdzono, że humor zastosowany w reklamie może być bardziej skuteczny w przekazywaniu jej wiadomości przez trzy różne sposoby: przez poprawę nastrojów ludzi, przyciągając uwagę i pomagając $\mathrm{w}$ zrozumieniu oraz w zwiększeniu pozytywnych postaw widzów odnośnie reklamy. ${ }^{14}$

\section{Zależność pomiędzy reklama a aktywnościa fizyczna}

Odnosząc się do poszczególnych opracowań naukowych zidentyfikowanych w trakcie przeglądu, należy wyróżnić w pierwszym rzędzie wyniki badań przeprowadzonych w Australii, Szkocji, Kanadzie oraz USA, które dotyczyły efektywności kampanii medialnych (m. in. narodowych i stanowych), w tym z wykorzystaniem reklamy telewizyjnej, zachęcających do intensyfikacji aktywności fizycznej dorosłych, a także skierowanych do dzieci. Wykazały one pozytywny efekt interwencji z udziałem mediów, czego wynikiem był wzrost wiedzy i świadomości na temat roli kultury fizycznej na zdrowie, choć nie zawsze przekładał się on na zmianę postaw i zachowań w tym zakresie lub zmiana ta miała charakter krótkotrwały. ${ }^{15-27}$

W wyniku badań wykazano, że reklamy propagujące szczupłe sylwetki osób ćwiczących mają istotny wpływ przede wszystkim na kobiety. Również reklamy przedstawiające ćwiczenia wykazały się wysoką skutecznością w zmianie postaw i zachowań w zakresie aktywności fizycznej. ${ }^{28}$ Ważnym aspektem jest również niska aktywność fizyczna wśród dzieci. W wyniku przeprowadzonych badań udowodniono, że reklamy ukazujące negatywne skutki otyłości dzieci oraz wpływ aktywności fizycznej na ograniczenie tego zjawiska, miały silny wpływ na matki. Zgadzały się one najczęściej, że brak aktywności fizycznej wśród dzieci jest problemem, jednak nie wszystkie matki dostrzegały ten problem wśród swoich dzieci. ${ }^{29}$ Należy zwrócić również uwagę na obszerne badanie wykonane w Australii, w którym wykorzystano reklamę telewizyjną do promocji 
commercials promoting low quality or unhealthy food and drinks by children and adolescents, and development of negative nutritional habits. ${ }^{31-33}$ The studies showed that TV commercials - with the use of persuasion techniques - have an impact on food preferences, consumption patterns, and are one of the main factors causing unhealthy diet and over-consumption in children, ${ }^{34-42}$ as well as consumption of products rich in fat, salt or sugar. ${ }^{43-45}$

The results show that television commercials promoting a slim body shape in teenagers, in consequence significantly affected their selfperception, which resulted in diagnosing in them eating disorders such as anorexia nervosa. ${ }^{46}$ Results of other studies highlight the strong impact of advertising of food products on overweight ${ }^{47-50}$ and obesity. ${ }^{51,52}$ Overweight and obesity are, in turn, risk factors in the origin and development of cardiovascular diseases, including hypertension, atherosclerosis, type II diabetes, degenerative joint diseases, or some types of cancer, particularly breast cancer and colon cancer. ${ }^{53,54}$ It has also been observed that overweight and obesity are risk factors in the emergence of psychosocial disorders in children and adolescents. ${ }^{55}$ It has been shown that the content of television commercials may cause bad mood, reduced self-confidence and dissatisfaction with their own body shape in women; in men, however, such influence has not been observed. ${ }^{56}$

\section{Similarities and differences between com- mercial and social advertising - analysis of health effects}

This review has identified and analysed studies that describe the relationship between messages, actions and campaigns by mass media, with a particular emphasis on television advertising, and human health effect. Previous studies showed healthy and anti-healthy behaviours in people, stimulated by mass media advertising. The presented results show that advertising can achieve a specific health effect which, in many cases, can be accurately assessed or investigated.

The first question to ask at this point is: how to understand the concept of health effect in the aktywności fizycznej społeczeństwa i zauważono istotny wzrost świadomości wraz ze zmianą zachowań populacji. ${ }^{30}$

\section{Wplyw reklamy na nawyki żywieniowe i po- wstawanie chorób}

Kolejnym obszarem tego artykułu były badania analizujące zależność pomiędzy oglądaniem reklamy w telewizji promującej niskiej jakości lub niezdrowe pożywienie i napoje u dzieci i dorastającej młodzieży a negatywnymi nawykami żywieniowymi. ${ }^{31-33}$

Wykazały one, że reklama telewizyjna - poprzez stosowane techniki perswazji - ma wpływ na preferencje żywieniowe, wzory konsumpcyjne, jest jednym z głównym czynników wpływających na niezdrową dietę i nadkonsumpcję u dzieci, ${ }^{34-42}$ a także spożywanie produktów z wysoką zawartością tłuszczu, soli i cukru. ${ }^{43-45}$

Wyniki badań pokazują, iż telewizja propagując szczupłe sylwetki u nastolatków, w istotny sposób wpływa na samopostrzeganie odbiorców tych reklam, co zaowocowało u nich zdiagnozowanymi zaburzeniami łaknienia $\mathrm{w}$ postaci jadłowstrętu. ${ }^{46}$ Wyniki innych opracowań podkreślają silne oddziaływanie reklamy produktów żywnościowych, której oddziaływanie skutkuje nadwagą ${ }^{47-50}$ oraz otyłością ${ }^{51,52}$ Nadwaga i otyłość są z kolei czynnikiem ryzyka w powstawaniu i rozwoju chorób układu sercowo-naczyniowego, w tym nadciśnienia tętniczego i miażdżycy, cukrzycy typu II, chorób zwyrodnieniowych stawów czy niektórych typów nowotworów, szczególnie nowotworów piersi i okrężnicy. ${ }^{53,54}$ Zaobserwowano również, iż nadwaga i otyłość są również czynnikiem powstawania zaburzeń psychospołecznych u dzieci i nastolatków ${ }^{55}$ Wykazano, że oglądanie reklamy telewizyjnej przez kobiety jest powodem ich złego nastroju, obniżonej pewności siebie i braku satysfakcji z własnej sylwetki w związku z treścią oglądanych obrazów, choć u mężczyzn nie stwierdzono takich zależności. ${ }^{56}$

Podobieństwa $i$ różnice pomiędzy reklama komercyjna a spoteczna - analiza skutków zdrowotnych

W pracy zidentyfikowano i poddano analizie 
context of the power of advertising that seems indisputable if it is able to change the behaviour and attitudes in such a crucial area of human life as the human health. The second question concerns the role of advertising: what is the purpose of its use? The answers to these questions require the analysis of the concepts of a health effect and the assessment of the impact of various factors on health associated with it, including advertising and the media, which it has at its disposal.

The concept of "a health effect" is related to the concept of "Health Impact Assessment" (HIA), which is understood as the method of assessment of the impact of policies, plans and projects in various sectors of the economy on health, using quantitative and qualitative techniques and participation, which focus on the assessment of various factors having positive or negative effects on health. The HIA helps in the selection of alternative solutions and improvements in order to avoid injury or disease, and can effectively promote health. ${ }^{57-59}$ The range of interests of the HIA is very broad and includes a number of public interventions that aim at achieving, through their implementation, a specific health effect such as a local network of social welfare infrastructure, routes of public transport, organization of tuition for young people, the safety of children who walk to school, localization of power stations, programs for the eradication of poverty, the health effects of unemployment, or the problem of anti-social behaviour. This means that the HIA procedures can be implemented for the previously identified problems, and thus can be considered as a helpful tool in shaping health policy. ${ }^{57-59}$ In Poland, the HIA is still developing, and among main stakeholders who may have a potential influence in the area of the effect of television advertising on human health are institutions such as the Ministry of Health, Ministry of Education, Ministry of Culture and National Heritage, Ministry of Sport and Tourism, and their subordinate offices such as the National Broadcasting Council and the Council of Ethics in Advertising. The institutions mentioned above can have a real impact on the form of advertisements because of the vested privileges: legislative, control, arbitral, opinion- badania opisujące zależności pomiędzy komunikatami, akcjami czy kampaniami mass-mediów, w tym ze szczególnym uwzględnieniem reklamy telewizyjnej a sytuacją zdrowotną człowieka. Dotychczasowe badania wykazały istnienie wpływu na zachowania prozdrowotne i antyzdrowotne ludzi, stymulowane przez reklamę medialną. Przedstawione wyniki badań wykazują, iż reklama może odnieść określony skutek zdrowotny, który niejednokrotnie można precyzyjnie ocenić lub zbadać.

Warto zatem w tym miejscu postawić pytanie, jak należy rozumieć pojęcie skutku zdrowotnego w kontekście siły reklamy, która wydaje się bezsporna, skoro jest ona w stanie zmieniać zachowania i postawy w tak newralgicznym obszarze ludzkiego życia, jakim jest ludzkie zdrowie. Drugim z pytań, jest kwestia roli reklamy - czemu ma ona służyć? W odpowiedzi na te pytania pomocna będzie analiza pojęcia skutku zdrowotnego i związanej z nim koncepcji oceny wpływu różnych czynników na zdrowie, a także reklamy i towarzyszących jej środków przekazu, jakimi ona dysponuje.

Z pojęciem skutku zdrowotnego związana jest cała koncepcja „Oceny wpływu na zdrowie” (Health Impact Assessment-HIA) rozumiana jako sposób oceny wpływu na zdrowie polityki, planów i projektów w różnych sektorach gospodarki, z zastosowaniem technik ilościowych, jakościowych oraz uczestnictwa, której przedmiotem jest ocena skutków różnych czynników w kontekście wystąpienia pozytywnych bądź negatywnych następstw zdrowotnych. HIA pomaga w dokonaniu wyboru alternatywnych rozwiązań i ulepszeń w celu uniknięcia urazu bądź choroby oraz pozwala aktywnie promować zdrowie. ${ }^{57-59}$ Zakres zainteresowań HIA jest bardzo szeroki i może obejmować wiele elementów publicznej interwencji $\mathrm{w}$ celu odniesienia przez ich implementację określonego efektu zdrowotnego, jak np. lokalna sieć infrastruktury pomocy społecznej, przebieg tras komunikacji publicznej, organizacja dokształcania młodzieży, bezpieczeństwo dzieci chodzących pieszo do szkół, lokalizacja elektrowni, programy zwalczania ubóstwa, zdrowotne skutki bezrobocia, problem antyspołecznych zachowań. Oznacza 
forming, and consultative in the field of prevention or avoidance of elements undesirable for health effects in children and adults in the advertised content. One of the latest examples of the socalled good practices in this area in Poland is the agreement signed by ITI Neovision, TVN, Polsat TV, Polish TV, TV Puls, VIMN Poland, The Walt Disney Company (Poland) and the Stavka company whereby from 1 January 2015 the programmes for children under 12 years aired by these broadcasters must not be accompanied by advertisements of unhealthy food, in particular, food or beverages whose components in excessive amounts in the daily diet of children are not advisable according to "Nutrition criteria for self-regulation concerning advertising of food directed at children under 12 years" issued at the request of the Polish Federation of Food and approved by the Ministry of Health. Another example of the so-called good practice in the area of regulation of advertising of medicinal products is the "Code of Good Practice for the Pharmaceutical Industry" functioning since 2014, and being an act which regulates responsible and ethical providing of information about the drug action, using an appropriate form and method of information communication.

As regards the concept of "advertising", it should be emphasized that dictionary definitions of advertising are closely related to communication in the field of management and marketing, which in itself determines its business connotation. ${ }^{60-66}$ One of many examples of definitions is provided, among others, in a scientific publication entitled "Strategic Marketing in Health Care" in the chapter "Designing Integrated Marketing Communication and its Management", where the concept of advertising is defined as a form of presentation and promotion of ideas, goods, or services by an identifiable sponsor. ${ }^{67}$ Its purpose is to persuade people to purchase or use presented goods or services. An advertising strategy involves, on the one hand, adjusting to the consumers' demands, and on the other, influencing them in order to achieve a profit. The main objectives of advertising are: creating product awareness, stimulating interest in the product and inducing a response in the form of its purchase. Contemporary advertising to, iż procedury HIA mogą być wdrażane z uwagi na wcześniej zidentyfikowane problemy i dlatego można je uznać za pomocne narzędzie w zakresie kształtowania polityki zdrowotnej. ${ }^{57-59} \mathrm{~W}$ Polsce HIA dopiero się rozwija, a wśród głównych interesariuszy, którzy mogą mieć potencjalny wpływ w kontekście treści tego opracowania, czyli wpływu reklamy telewizyjnej na obszar zdrowia można wyróżnić takie instytucje, jak: Ministerstwo Zdrowia, Ministerstwo Edukacji, Ministerstwo Kultury i Dziedzictwa Narodowego, Ministerstwo Sportu i Turystyki wraz z podległymi im urzędami, a także Krajową Radę Radiofonii i Telewizji oraz Radę Etyki Reklamy. Wymieniono je dlatego, iż instytucje te mogą mieć realny wpływ na kształt reklam z uwagi na przysługujące im uprawnienia bądź prawodawcze, bądź kontrolne bądź arbitrażowe, opiniotwórcze i doradcze w zakresie zapobiegnięcia bądź unikania $\mathrm{w}$ treściach reklam elementów dysfunkcjonalnych dla skutków zdrowotnych dzieci i dorosłych. Jeden z najnowszych polskich przykładów tzw. dobrych praktyk w tym zakresie dotyczy porozumienia podpisanego przez ITI Neovision, TVN, Telewizję Polsat, Telewizję Polską, Telewizję Puls, VIMN Poland, The Walt Disney Company (Polska) oraz spółkę Stavka, w ramach którego od 1 stycznia 2015 r. audycjom dla dzieci do 12 lat emitowanym przez tych nadawców nie będą towarzyszyły reklamy tzw. niezdrowej żywności, a w szczególności artykułów spożywczych lub napojów zawierających składniki, których obecność w nadmiernych ilościach w codziennej diecie dzieci jest niewskazana zgodnie z „Kryteriami żywieniowymi do samoregulacji dotyczącej reklamy żywności skierowanej do dzieci poniżej 12 lat" opracowanymi na zlecenie Polskiej Federacji Producentów Żywności i zaakceptowanymi przez Ministerstwo Zdrowia. Innym przykładem tzw. dobrej praktyki na poziomie regulacji obszaru reklamy produktów leczniczych jest Kodeks Dobrych Praktyk Przemysłu Farmaceutycznego funkcjonujący od 2014 roku, będący aktem normującym w zakresie odpowiedzialnego i etycznego informowania o działaniach leku z zachowaniem odpowiedniej formy i sposobu przekazu.

Przechodząc do pojęcia reklamy należy pod- 
has a variety of forms: from a reliable information about the benefits of the product or service, and ending with unreliable ones, misleading the potential customers, as for example, commercial advertisements. The main purpose of advertising is the impact on customers and, as a result, the level of sale of goods and services. ${ }^{67,68}$

An important element of the analysis of the relationship between advertising and health is the issue of the impact of advertising on children, since the investigations conducted in Poland show that advertisements, apart from animated films, are the most frequently watched and the most popular elements of television programs, and, what is more, the vast majority of children aged between 5-10 years approve commercials and, similarly preschool children not only approve of them, but also enjoy watching them. ${ }^{69}$

The three main features of advertising are: persuasiveness (the repetition of the same message), enhanced expression (artistic use of print, sound and colour) and impersonality (an advertisement is a monologue and not a dialogue). ${ }^{67}$ The main functions of advertising are: ${ }^{67}$

- the informative function related to the creation of brand awareness and providing information about products (new or existing ones),

- the persuasive function which aims at eliciting a positive approach towards the product or service, the inclination to prefer a particular brand. This type of advertising means comparative advertising, showing the product in comparison with other products or services,

- the reminding function which stimulates the sale of products or services,

- the enhancing function which aims at making buyers believe that through the purchase of a specific product they make the right choice.

The aims of advertising are classified as: ${ }^{68}$

- perlocutionary - to evoke desire to possess a particular product / service,

- persuasive - to encourage the recipient to purchase a certain product, which will give them contentment, and the satisfaction of having the product or service, kreślić, iż podręcznikowe definicje i rozumienie reklamy są ściśle związane ze sferą zarządzania i komunikacji marketingowej, co już samo w sobie wyznacza jej biznesową konotację. ${ }^{60-66}$ Jeden z wielu przykładów definicji zawarto m.in. w publikacji naukowej pt. „Marketing strategiczny w opiece zdrowotnej" w rozdziale "Projektowanie zintegrowanej komunikacji marketingowej i zarządzanie nią", gdzie pojęcie reklamy zdefiniowano jako forma prezentacji i promocji pomysłów, dóbr lub usług przez dającego się zidentyfikować sponsora. ${ }^{67}$ Jej celem zaś jest nakłonienie do zakupu lub skorzystania z prezentowanych towarów bądź usług. Strategią reklamy jest z jednej strony dostosowywanie się do potrzeb odbiorców, a z drugiej wpływanie na nabywców w celu osiągnięcia zysku. Do głównych celów reklamy zalicza się: budowanie świadomości produktu, pobudzenie zainteresowania produktem i wywołanie reakcji w postaci jego zakupu. Współczesna reklama ma różne odmiany począwszy od rzetelnego przekazu informującego o zaletach produktu czy usługi, a skończywszy na nierzetelnych, wprowadzających potencjalnego odbiorcę w błąd, jak np. reklama komercyjna. Głównym celem reklamy jest wpływ na odbiorców i w efekcie na poziom sprzedaży dóbr i usług. ${ }^{67,68}$

Istotnym elementem analizy zależności pomiędzy reklamą a zdrowiem jest kwestia oddziaływania reklamy na dzieci z uwagi na wyniki badań polskich, które wskazują, że reklamy, oprócz filmów animowanych, stanowią najczęściej oglądany i najbardziej lubiany element programów telewizyjnych, zdecydowana większość dzieci w przedziale 5-10 wyraża aprobatę wobec reklam a z kolei dzieci w wieku przedszkolnym nie tylko je akceptują, ale również lubią je w bardzo dużym odsetku. ${ }^{69}$

Trzy główne cechy reklamy to: perswazyjność (wielokrotne powtarzanie tej samej wiadomości), wzmocniona ekspresja (artystyczne wykorzystanie druku, dźwięku, koloru) i bezosobowość (reklama jest monologiem, a nie dialogiem). ${ }^{67}$ Wśród głównych funkcji reklamy wyróżnia się: ${ }^{67}$

- funkcję informacyjną związaną z tworzeniem świadomości marki i informacji o produktach (nowych lub już istniejących), 
- informative - to submit vital information about the product or service.

An important area of advertising is the concept of social advertising, which, in terms of the final effect, does not differ much from commercial advertising. The purpose of commercial advertising is to attract a person to a product or service, whereas the purpose of social advertising is to draw attention to an existing problem or issue. ${ }^{68}$

Social advertising employs the techniques used in commercial advertising, although its purpose is not persuading people to buy a product, but trying to convince people to certain idea, to provoke a change in behaviour, or induce a certain attitude towards, for example, important social problems. Despite the use of similar media, the essential difference between social and commercial advertising is the aims of the messages they convey. The purpose of social advertising is to induce certain attitudes and socially desirable behaviours, or cessation of the harmful ones, while the goal of commercial advertising is also, apart from providing information, to induce the change of behaviour and attitudes - persuading to buy a product or service by changing the recipients' attitude to the promoted product. The intention of social advertising is to help people, unlike commercial advertising whose intention is profit, frequently connected with an attempt to deceive a potential consumer. ${ }^{70}$

One of the first examples of social advertising in Poland was a joint campaign of the Polsat Foundation and Procter \& Gamble Company under the name "Give Children the Sun" implemented in the years 1999-2000, whose aim was to help sick children. Part of this TV campaign advertised the products of Procter \& Gamble Company marked with the slogan "Give Children the Sun" aired mainly by Polsat TV and TVP 1, TVP 2, TVN and RTL 7. As a result, funds of $€ 4.8$ million were collected, whereby the following projects could be finalized: the creation of a cord blood bank, a family program of liver transplantations and the creation of the children's oncology department in Wroclaw. One of the aims of this media campaign was to raise funds for the Children's Burn Centre. ${ }^{71}$ In this case, the relationship was observed between
- funkcję perswazyjną mającą na celu wywołanie pozytywnego nastawienia do produktu lub usługi, skłonności do preferowania określonej marki; ten typ reklamy oznacza stosowanie reklamy porównawczej z innymi produktami/usługami,

- funkcję przypominającą służącą do stymulowania sprzedaży produktów lub usług,

- funkcję wzmacniającą mającą na celu utwierdzenie nabywców w przekonaniu, iż poprzez zakup dokonali właś ciwego wyboru.

Innym rozróżnieniem celów reklamy jest podział ze względu na cel: ${ }^{68}$

- perlokucyjny mający wywołać pożądanie posiadania danego produktu/usługi,

- perswazyjny mający zachęcić odbiorcę do zakupu, który da mu zadowolenie, satysfakcję z posiadania produktu bądź usłu gi,

- informacyjny dotyczący przekazywania najistotniejszych informacji o produkcie bądź usłudze.

Szczególnym obszarem reklamy jest pojęcie reklamy społecznej, która z racji oczekiwanego skutku nie różni się od reklamy komercyjnej. Celem reklamy komercyjnej jest bowiem przyciągnięcie do produktu czy usługi, a celem reklamy społecznej zwrócenie uwagi na jakiś problem, sprawę. ${ }^{68}$

W reklamie społecznej wykorzystywane są techniki stosowane w reklamie komercyjnej, choć jej celem nie jest nakłanianie kogoś do zakupu czegoś, ale próba przekonania do jakiejś idei, zmiany zachowania, wywołania określonej postawy, np. wobec ważnych problemów społecznych. Mimo podobieństw w środkach przekazu, zasadniczą różnicą pomiędzy reklamą społeczną a komercyjną są cele stawiane przez dwa rodzaje komunikatów. Celem reklamy społecznej jest wywołanie postaw i zachowań społecznie pożądanych (lub zaniechanie szkodliwych), a celem komunikatów komercyjnych - również polegających nie tylko na informowaniu, bo również ich celem jest zmiana zachowań i postaw - jest nakłonienie do kupna produktu bądź usługi poprzez zmianę stosunku odbiorców do promowanego produktu. Intencją reklamy społecznej jest pomoc innym, a intencją komercyjnej - zysk, w tym niejednokrotnie przy próbie oszukania potencjalnego konsumenta. ${ }^{70}$ 
the funds raised as a direct result of advertising and its indirect health effect in the form of establishing the infrastructure for saving life and restoring health in children. ${ }^{72}$

An example of one of the recent media campaigns on a large scale, connected with social advertising in Poland, was television advertisements emitted by one of the mobile networks, persuading to take part in the finals of the Great Orchestra of Christmas Charity (GOCC) in January 2015, with the aim of collecting funds for paediatric, paediatric-oncological and geriatric hospital departments and care-and-treatment institutions. In this type of advertisement, the relationship between its broadcast and indirect health benefits was observed, since the funds collected during the GOCC campaign were used for equipping the infrastructure and medical apparatus for paediatric and geriatric patients. ${ }^{72,73}$

Another interesting example of social advertising on an international scale was a television advertisement displaying a football game played by men sitting in armchairs under the slogan "Go on, get out of your armchair" aired during the UEFA Champions League. The aim of this media campaign was to encourage physical exercise, since the statistics show that, on average, every second adult European suffers from overweight or obesity. According to the WHO, malnutrition in the form of an imbalanced diet coupled with low physical activity belong to the seven most important health risk factors in the Europeans. According to estimates, the media campaign under the slogan "Get Active!" reached approximately 80-100 million recipients during each week of football UEFA Champions League. The campaign was aired in forty countries in Europe due to granting free airtime by UEFA in order to issue this advertisement. ${ }^{72,74}$

Analysing the examples of commercial advertising in the context of health effects, it is worth noting the investigations which show its positive and negative impact on health. Referring to the advertising of drugs, it was found that television commercials concerned with a particular disease were associated with an increased awareness of this disease and a greater number
Jednym z pierwszych przykładów wpisujących się w nurt reklamy społecznej w Polsce była wspólna akcja Fundacji Polsatu i firmy Procter\&Gamble pod nazwą „Podaruj Dzieciom Słońce" realizowana w latach 1999-2000 skoncentrowana na działaniach na rzecz pomocy chorym dzieciom. W ramach tej kampanii reklamowano produkty Procter\&Gamble oznakowane hasłem „Podaruj Dzieciom Słońce” emitowane głównie na antenie telewizji Polsat oraz w TVP1, TVP2, TVN i RTL7, w efekcie których zgromadzono środki finansowe w wysokości 4,8 mln, dzięki którym sfinalizowano: utworzenie banku krwi pępowinowej, program rodzinnych przeszczepów wątroby oraz stworzenie dziecięcego oddziału onkologicznego we Wrocławiu. Jednym z celów kampanii było także zebranie funduszy na Dziecięce Centrum Oparzeniowe. ${ }^{71}$ Nastąpiła tutaj zatem zależność pomiędzy zebranymi funduszami jako bezpośrednim efektem reklamy a jej pośrednim skutkiem zdrowotnym, w postaci stworzenia infrastruktury służącej ratowaniu życia i zdrowia dzieci. $^{72}$

Przykładem jednej z najnowszych akcji o dużym zasięgu dotykającym reklamy społecznej w Polsce były reklamy w TV emitowane z jedną $\mathrm{z}$ sieci telefonii komórkowej namawiające do wzięcia udziału w finale Wielkiej Orkiestry Świątecznej Pomocy (WOŚP) w styczniu 2015 r., których celem było zebranie środków pieniężnych na rzecz szpitalnych oddziałów pediatrii i onkologii dziecięcej oraz oddziałów geriatrycznych i zakładów opiekuńczo-leczniczych. W przypadku tej reklamy również zaszła zależność pomiędzy jej emisją a pośrednim skutkiem zdrowotnym, gdyż zebrane w trakcie WOŚP fundusze, zostały przeznaczono na doposażenie infrastruktury i aparatury medycznej dla pacjentów pediatrycznych i geriatrycznych. ${ }^{72,73}$

Innym interesującym przykładem reklamy społecznej o zasięgu międzynarodowym była reklama telewizyjna wyświetlająca mecz piłki nożnej rozgrywany przez siedzących na fotelach mężczyzn pod hasłem "Go on, get out of your armchair" emitowana w trakcie rozgrywek Ligi Mistrzów UEFA. Celem kampanii było zachęcenie do ćwiczeń fizycznych z uwagi na statystyki pokazują- 
of its diagnoses. These studies demonstrated an increased number of diagnosed hyperlipidemia ${ }^{3}$ and onychomycosis ${ }^{2}$ as a result of TV advertising. It may be inferred from this example that people who were previously unaware of having a certain disease, after watching an advertisement noticed similar symptoms which prompted them to initiate diagnostic procedures and treatment. ${ }^{2,3}$ Another study found that both a ban on alcohol advertising and advertising against alcohol consumption were associated with a reduction in the cost of treatment of diseases related to alcohol intake. ${ }^{75}$ One of the studies dealing with watching television and overweight in adolescents and children showed that female teenagers who compulsively watched television pay great attention to a tall and slim figure. This had a significant impact on their selfperception and resulted in their being diagnosed with eating disorders such as anorexia. ${ }^{46}$ Other studies revealed a significant impact of advertising on bad eating habits in children, which resulted in their overweight ${ }^{47-50}$ and obesity. ${ }^{51,52}$ In one of these studies, a strong correlation was observed between the incidence of obesity in children and the time spent on watching television. ${ }^{49}$ Another research study showed that reduced time of watching television by children led to their weight reduction. ${ }^{50}$

Referring to the influence of advertising on children already stressed in this article, attention should be paid to the study demonstrating that watching commercials by preschool children leads not only to development of beliefs in false suggestions coming from advertisements, but also to inducing strong stimuli in the form of various feelings and associations. ${ }^{75}$ The studies carried out among children disclose the impact of advertising on children's mental health and their cognitive sphere. Adverse effects may involve the creative activity and imagination of a child, or pose a threat to his/her proper learning of vocabulary and pronunciation. Apart from a negative and direct impact on health, a negative attitude was identified in children in the social aspect, manifested by a demanding attitude towards parents, which was the consequence of watched advertisements. ${ }^{75}$ ce, iż średnio co drugi dorosły Europejczyk cierpi na nadwagę bądź na otyłość, a według danych WHO niewłaściwe odżywianie $\mathrm{w}$ postaci braku zrównoważonej diety i niski poziom aktywności fizycznej należą do siedmiu najpoważniejszych czynników ryzyka problemów zdrowotnych w Europie. Według szacunkowych danych kampania pod hasłem „Get Active!” dotarła do ok. 80100 milionów odbiorców w czasie każdego tygodnia rozgrywek piłkarskich Ligi Mistrzów UEFA. Kampania została wyemitowana w 40 państwach Europy dzięki temu, iż UEFA udostępniła wolny czas antenowy na emisję tej reklamy. ${ }^{72,74}$

Analizując przykłady reklamy komercyjnej w kontekście jej skutków zdrowotnych warto zwrócić uwagę na wyniki badań, które wskazują na pozytywny bądź negatywny jej wpływ na zdrowie. Nawiązując do reklam leków, badania wykazały, że reklama telewizyjna określonej jednostki chorobowej wiązała się ze wzrostem świadomości społeczeństwa oraz większą liczbą zdiagnozowanych przypadków określonej choroby. W wyniku jednego z badań wzrosła częstość diagnozowania hiperlipidemii, ${ }^{3}$ natomiast drugiego grzybicy paznokci. ${ }^{2}$ Wnioskować $\mathrm{z}$ tego można, że osoby wcześniej nieświadome, po kampanii reklamowej zaczęły leczyć się na zdiagnozowaną u nich chorobę, bądź dostrzegły u siebie podobne objawy, co skłoniło je do podjęcia decyzji o przebadaniu się. ${ }^{2,3} \mathrm{~W}$ innym badaniu stwierdzono, że zakaz reklamy alkoholu oraz kampanie przeciwko piciu alkoholu wiążą się z zmniejszeniem kosztów leczenia chorób związanych z piciem alkoholu. ${ }^{75}$ Warto również nawiązać do wyników badań, które zostały przedstawione już wcześniej. W jednym z nich wykazano, że nastolatki uzależnione od telewizji zwracają dużą uwagę na sylwetki wysokich i szczupłych kobiet. Ma to istotny wpływ na sposób samopostrzegania oraz zaowocowało wśród nich zdiagnozowanymi zaburzeniami łaknienia $\mathrm{w}$ postaci jadłowstrętu. ${ }^{46} \mathrm{~W}$ kolejnych badaniach wykazano istotny wpływ reklamy na złe nawyki żywieniowe wśród dzieci, co wiąże się znowu $\mathrm{z}$ występującą wśród nich nadwagą ${ }^{47-50}$ i otyłością. ${ }^{51,52} \mathrm{~W}$ jednym $\mathrm{z}$ nich zaobserwowano silną zależność pomiędzy występowaniem otyłości wśród dzieci a liczbą godzin oglądania tele- 
The researchers of this problem observed a threefold impact of advertising on children's personality: ${ }^{69}$

- the direct influence as it can be observed immediately after watching the advertisement, which is manifested by spontaneous expression of feelings,

- the cumulative effect which lasts longer hardly noticeable at first, gradually becoming more and more visible,

- the subconscious influence which occurs unconsciously, where the content and images enter psyche and are felt after some time.

In this particular context, the impact of advertising manipulation seems to be a significant problem not only in children, but also in adults due to its hidden persuasion. The buyer, who theoretically has the possibility of choosing a product or service, is in practice constantly inundated by messages, which may lead to the loss of the ability to think rationally, and thereby the ability to choose. Equally important is the fact that the viewer of television advertising during its broadcast does not perceive real situations but carefully selected elements, which may lead to distortion and manipulation. ${ }^{76,77}$ The manipulation of the recipients' emotions by advertising has a definite purpose - instead of giving free choice, it is focused on authoritarian transmission and the lack of the possibility of critical analysis of other options when watching commercial spots, and results in imposing a particular style of life or consumptive attitudes. The image thus created by television advertising, if not realized by its recipient, can generate in him/ her the feeling of frustration and even decreased self-esteem. ${ }^{78,79}$

\section{Summary}

Referring to the examples of television actions or campaigns presented in this article, it must be stressed that advertising can exert influence through the mass media, and their goal is to change the recipients' attitudes or behaviour. Commercial and social advertising are similar in influencing the viewers mainly by persuasion. The difference between these two types of advertising wizji. ${ }^{49} \mathrm{~W}$ kolejnym natomiast stwierdzono, że zmniejszenie częstotliwości oglądania telewizji, wiąże się ze spadkiem wagi u dzieci. ${ }^{50}$

Odnosząc się do akcentowanej już w tym artykule siły reklamy adresowanej do dzieci, warto zwrócić uwagę na badania, które wykazały, iż oglądanie reklam u dzieci przedszkolnych prowadzi do sytuacji, w których dzieci nie tylko wierzą $\mathrm{w}$ fałszywe sugestie płynące $\mathrm{z}$ reklam, ale wywołują one $\mathrm{w}$ nich silny bodziec $\mathrm{w}$ postaci wielu uczuć i skojarzeń. ${ }^{75}$ Badania przeprowadzone wśród dzieci dowodzą również wpływu reklamy na ich zdrowie psychiczne i wskazują na negatywny wpływ na sferę poznawczą, a negatywne zmiany mogą dotykać twórczej aktywności i wyobraźni dziecka czy też zagrożenia dla prawidłowego rozwoju słownictwa i wymowy. Oprócz negatywnego i bezpośredniego wpływu na zdrowie zidentyfikowano także negatywną postawę wśród dzieci w aspekcie społecznym objawiającą się w postawie roszczeniowej wobec rodziców będącą efektem oglądanych reklam. ${ }^{75}$

Badacze problemu zaobserwowali trojaki wpływ reklamy na osobowość dzieci objawiający się: ${ }^{69}$

- wpływem bezpośrednim, jaki jest możliwy do zaobserwowania bezpośrednio po obejrzeniu reklamy i przejawiający się w żywiołowym uzewnętrznianiu się uczuć,

- wpływem kumulatywnym, który przebiega w dłuższej perspektywie czasowej - początkowo mało zauważalny, stopniowo coraz bardziej widoczny,

- wpływem podświadomym, jaki zachodzi nieświadomie, a treści i obrazy dochodzą do psychiki dając o sobie znać dopiero po jakimś czasie.

Szczególnie w tym kontekście wydaje się istotny problem wpływu manipulacji reklamy nie tylko na dzieci, ale również i na dorosłych z uwagi na jej ukrytą perswazję. Nabywca, który teoretycznie dysponuje możliwością wyboru produktu lub usługi, jest w praktyce bezustannie zasypywany komunikatami, które mogą doprowadzić do zatracenia zdolności racjonalnego myślenia i tym samym wyboru. Co równie istotne, odbiorca reklamy telewizyjnej, w trakcie jej nadawania, nie od- 
lies in the fact that in commercial advertising a business result is understood as the profit from the sale of products or services, whereas in social advertising a result takes the form of the recipient's awareness of an existing problem or idea. As a rule, the aim of social advertising has a positive health effect, and commercial advertising can have both a positive and negative health effect. The negative effect of advertising is related to harmful nutritional habits, which may lead to an increased blood cholesterol level, blood glucose level and a higher risk of atherosclerosis. The positive effect of commercial advertising may occur when some products are advertised for profit, but its broadcasting may simultaneously induce positive results, even secondary ones. ${ }^{2,3}$ In this sense, the role of social advertising is also twofold. On the one hand, it may encourage certain positive behaviour, e.g. pro-health, but on the other hand, it may be the means of persuasion, which can indicate attitudes that are undesired from the social or health point of view. It also indicates a focus on messages aimed at showing how to achieve the desired health effect or how to cease undesired activities so as to prevent the occurrence of adverse health effects. ${ }^{80}$

A particular area of advertising, and at the same time a threat, involves messages addressed to children, which are frequently accepted by them uncritically, which may lead to adverse health effects due to the advertised content. The investigations into this problem indicate that television is an effective medium of reaching recipients via advertising of products for children and adolescents, ${ }^{81}$ and the general accessibility of television and the Internet makes it possible to influence people by advertising e.g. alcohol, cigarettes, sex, or medicines and food that leads to obesity and are harmful to children. This is all the more dangerous, since the results of studies stress the significant impact of television on young people. ${ }^{82}$ It must be remembered that regardless of the target group of advertising - children or adults - advertising bases its strength on playing with emotions, and through its instruments tries to influence changes in behaviour or attitudes, hence the correct recognition of real intentions biera rzeczywistości bezpośredniej, ale starannie wybrane elementy, co może prowadzić do przekłamań i manipulacji. ${ }^{76,77}$ Element manipulowania emocjami odbiorców ma określony cel - reklama zamiast pozostawiać wolny wybór, nastawiona jest na autorytarny przekaz, a brak w spotach reklamowych możliwości kształtowania krytycznej analizy innych wariantów, skutkuje narzucaniem określonego stylu życia czy postaw konsumpcjonistycznych. W ten sposób wykreowana przez reklamę telewizyjną wizja, jeśli nie będzie mogła zostać zrealizowana przez odbiorcę reklam, może w nim wywołać poczucie frustracji, zaniżenia samooceny czy wręcz obniżenia poczucia wartości. 78,79

\section{Podsumowanie}

Odnosząc się do zaprezentowanych w tym artykule przykładów akcji czy kampanii medialnych z udziałem telewizji, należy podkreślić, iż reklama może wpływać za pomocą swoich środków przekazu, których celem jest zmiana postaw lub zachowań. Zarówno reklama komercyjna, jak i społeczna wykazuje podobieństwo w zakresie wpływania na odbiorców za pomocą m.in. perswazji. To, co różni te dwa rodzaje reklamy, to w przypadku reklamy komercyjnej skutek biznesowy w postaci zysku ze sprzedaży produktów lub usług, a w przypadku reklamy społecznej skutek w postaci uświadomienia odbiorcy jakiegoś problemu, idei. Co do zasady, reklama społeczna ma odnieść pozytywny skutek dla zdrowia, a reklama komercyjna może zaś przynieść zarówno negatywny, jak i pozytywny skutek zdrowotny. Negatywny efekt reklamy jest związany z nabyciem szkodliwym nawyków żywieniowych, które skutkować mogą wzrostem poziomu cholesterolu, glukozy we krwi czy wyższym ryzykiem rozwoju miażdżycy. Pozytywny skutek reklamy komercyjnej może nastąpić w sytuacji, w której ktoś reklamuje jakieś produkty dla zysku, ale emisja może odnieść również skutek pozytywny, nawet wtórny. ${ }^{2,3} \mathrm{~W}$ tym sensie rola i skutki reklamy społecznej są również dwojakie. $\mathrm{Z}$ jednej strony, może być czynnikiem zachęcającym do pewnych zachowań np. prozdrowotnych, a z drugiej, środkiem perswazji, który może wskazywać na postawy społecznie lub zdrowotnie 
of advertisers can protect the viewers from negative health effects. Social advertising seems to be an ally when it comes to informing people about matters relevant and useful for a particular population, and therefore, the development of this kind of trend seems to be a desirable phenomenon both for public health and the widely understood sphere of social life.

The importance of medical and social dimension of the impact of advertising - including television advertising - on health was also noted by the Polish Chamber of Physicians and Dentists in Warsaw, which took relevant action following repeated cases of the participation of doctors in commercials of, among others, drugs and other therapeutic products, as well as dietary supplements. With regard to this issue, the Chief Professional Responsibility Officer, Dr Grzegorz Wrona, on 26 January 2016 issued the following statement: "In accordance with the provisions of the Code of Medical Ethics (Article 63), the physician should not give consent to the use of his/her name and likeness for commercial purposes. It means that physicians and dental practitioners cannot appear in commercials - this concerns not only the advertising of medicines (medicinal products), for which it is prohibited under the provisions of the Pharmaceutical Law, but also all other products including medical devices or dietary supplements. Doctors and dental practitioners who violate the above provision of the Code of Medical Ethics (CME) have to reckon with the fact that they bear responsibility for this profession-proceedings in such cases are initiated by Attorneys of Professional Responsibility, who will then bring lawsuits in medical courts. Proceedings which have already been carried out ended with a judgment of guilt, and the most frequent punishment was a caution and financial penalties (...)". ${ }^{83}$

This message was a consequence of a series of cases involving the infringement of Article 63 paragraph $2 \mathrm{CME}$ (for permission to use the name and likeness for commercial purposes), conducted by the District Attorneys of Professional Responsibility. In the years 20132015 they conducted 42 cases, 26 of which ended niepożądane, co oznacza koncentrację na komunikatach reklamowych zmierzających do tego co robić, aby uzyskać zamierzony skutek zdrowotny lub wpłynąć na zaniechanie, aby uchronić przed negatywnym skutkiem zdrowotnym. ${ }^{80}$

Szczególnym obszarem reklamy i jednocześnie zagrożenia są komunikaty tego typu adresowane do dzieci, które to często przyjmują je bezkrytycznie, co może w efekcie skutkować negatywnymi skutkami dla zdrowia jej odbiorców z uwagi na prezentowane $\mathrm{w}$ reklamach treści. Jest to tym bardziej istotne, gdyż wyniki badań wskazują, iż telewizja jest efektywnym medium docierania poprzez reklamę produktów dla dzieci i nastolatków, ${ }^{81}$ a jej ogólna dostępność poprzez ekran telewizora i drogą internetową stwarza możliwość dotarcia z reklamą alkoholu, papierosów, promocją seksu, czy szkodliwych dla dzieci leków i reklamą żywności prowadzącą do otyłości. Jest to tym bardziej niebezpieczne $\mathrm{z}$ uwagi na wyniki badań, które pokazują, iż wpływ telewizji na młodych ludzi można określić jako znaczący. ${ }^{82}$ Warto również pamiętać i o tym, że niezależnie od grupy docelowej reklam - czy jest ona skierowana do dzieci czy dorosłych - reklama opiera swoją siłę na graniu emocjami, a poprzez swoje instrumentarium chce wpływać na zmianę zachowań czy postaw, stąd prawidłowe rozpoznanie rzeczywistych intencji reklamodawców może uchronić jej odbiorców przed negatywnymi skutkami zdrowotnymi. Reklama społeczna wydaje się z kolei być sprzymierzeńcem informowania o sprawach istotnych i użytecznych dla danej populacji, a zatem rozwijanie tego rodzaju nurtu, wydaje się być zjawiskiem pożądanym zarówno od strony zdrowia publicznego, jak i szeroko pojętej sfery życia społecznego.

Waga medycznego i społecznego wymiaru wpływu reklamy - w tym reklamy telewizyjnej - na zdrowie została również dostrzeżona przez Naczelną Izbą Lekarską w Warszawie, która podjęła stosowne działania w ślad za powtarzającymi się przypadkami udziału lekarzy w reklamach m.in. leków oraz innych produktów leczniczych i suplementów diety. W związku z tym Naczelny Rzecznik Odpowiedzialności Zawodowej NIL dr Grzegorz Wrona wystosował w dniu 26 stycz- 
with requests for punishment filed with regional medical courts. ${ }^{83}$

\section{Conclusions}

The analysis of the results of studies and specific examples of media campaigns and actions in the area of social and commercial advertising presented in this article, allow one to draw the following conclusions:

Advertising influences the recipients through its media, whose aim is to change attitudes and behaviours and, as a result, may generate intentionally or unintentionally - a health effect.

Television advertising can have both positive and negative health effect. The first one is usually associated with social advertising, although commercial advertising may be accompanied by a pro-health message.

There is a relationship between watching TV and its impact on the pro- and anti-health attitudes in such sensitive areas for population health as smoking, physical activity, diet, and consumption of medication.

Children and adolescents are particularly vulnerable to the influence of advertising because of their susceptibility to this type of messages coupled with the lack of sufficient criticism in the assessment of conformity with reality, which results in the recognition of advertising spots as true.

Commercial advertising may be dangerous for its recipients, due to the fact that advertisers, through presentations of their products and services, can create the consumer culture, often not having much in common with the reality in which the recipient of advertising lives. This can have a negative impact on the recipient in the form of frustration, self-underestimation or decreased self-esteem.

It seems appropriate to develop and implement certain measures of a preventive or interventional character by relevant authorities, using the procedures and tools created under the concept of "Health Impact Assessment" in order to minimize or eliminate the negative health effect of advertising. nia 2016 roku komunikat o następującej treści: „Zgodnie z przepisami Kodeksu Etyki Lekarskiej (art. 63) lekarz nie powinien wyrażać zgody na używanie swojego nazwiska i wizerunku dla celów komercyjnych. Oznacza to, że lekarze i lekarze dentyści nie mogą brać udziału w reklamach - dotyczy to nie tylko reklamy leków (produktów leczniczych), co do których jest to zabronione na mocy przepisów Prawa farmaceutycznego, ale także wszelkich innych produktów, włącznie z produktami będącymi wyrobami medycznymi czy suplementami diety. Lekarze i lekarze dentyści naruszający ww. przepis Kodeksu Etyki Lekarskiej (KEL) muszą się liczyć z tym, że poniosą za to odpowiedzialność zawodową - postępowania $\mathrm{w}$ takich przypadkach są wszczynane przez rzeczników odpowiedzialności zawodowej, którzy następnie kierują wnioski o ukaranie do sądów lekarskich. Postępowania, które już zostały przeprowadzone, zakończyły się orzeczeniem winy, a najczęściej orzeczoną karą były kary upomnienia i kary pieniężne (...)"83

Komunikat ten był następstwem szeregu spraw dotyczących naruszenia art. 63 ust. 2 KEL (dotyczącego zgody na używanie nazwiska i wizerunku dla celów komercyjnych), prowadzonych przez Okręgowych Rzeczników Odpowiedzialności Zawodowej. W latach 2013-2015 prowadzili oni bowiem 42 sprawy, które 26 przypadkach zakończyły się wnioskami o ukaranie skierowanymi do okręgowych sądów lekarskich. ${ }^{83}$

\section{Wnioski}

Przedstawiona w artykule analiza wyników badań oraz konkretnych przykładów kampanii, a także akcji z zakresu reklamy społecznej i komercyjnej upoważniają do wyciągnięcia następujących wniosków:

Reklama wpływa na odbiorcę poprzez swoje środki przekazu, których celem jest zmiana postaw lub zachowań i w efekcie może przynieść - zamierzony lub niezamierzony - skutek zdrowotny.

Reklama telewizyjna może mieć zarówno pozytywny, jak i negatywny wpływ na zdrowie. Ta pierwsza zależność jest z reguły związana z emisją reklamy społecznej, choć i reklamie komercyj- 
nej może towarzyszyć pozytywny przekaz, np. na rzecz postaw prozdrowotnych.

Wyniki badań wskazują na zależność pomiędzy oglądaniem telewizji a wpływem na postawy pro$i$ antyzdrowotne $w$ tak newralgicznych obszarach dla zdrowia populacji jak palenie papierosów, aktywność fizyczna, sposób odżywiania, czy konsumpcja leków.

Szczególnie narażone na wpływ reklam są dzieci i dorastająca młodzież z uwagi na ich podatność na tego typu komunikaty połączoną z brakiem dostatecznej dozy krytycyzmu w zakresie oceny zgodności z rzeczywistością, co skutkuje uznawaniem spotów reklamowych za prawdziwe.

Niebezpieczeństwem dla odbiorów reklam komercyjnych może być fakt, że reklamodawcy, poprzez prezentacje swoich produktów i usług, mogą wykreować i wytworzyć styl kultury konsumpcyjnej niejednokrotnie nie mający wiele wspólnego z rzeczywistością, w jakiej żyje odbiorca reklamy, co może mieć na niego negatywny wpływ w postaci frustracji, zaniżenia samooceny czy obniżenia poczucia wartości.

Wydaje się za właściwe opracowywanie i wdrażanie pewnych działań o charakterze prewencyjnym bądź interwencyjnym przez odpowiednie do tego instytucje wykorzystując do tego procedury i narzędzia wypracowane w ramach koncepcji Health Impact Assessment w celu zminimalizowania bądź wyeliminowania negatywnych skutków dla zdrowia w obszarze reklamy.

\section{References}

1. Higgins JPT, Green $S$, editors: Cochrane Handbook for Systematic Reviews of Interventions Version 5.1.0 updated March 2011. The Cochrane Collaboration, 2011. Available from http: //handbook.cochrane.org.

2. 't Jong GW, Stricker BH, Sturkenboom MC: Marketing in the lay media and prescriptions of terbinafine in primary care: Dutch cohort study. BMJ 2004; 328: 931

3. Zachry W, Shepherd MD, Hinich MJ, Wilson JP, Brown CM, Lawson KA: Relationship between di- rect-to-consumer advertising and physician diagnosing and prescribing. Am J Health Syst Pharm 2002; 59: 42-49.

4. Kravitz RL, Epistein RM, Feldman MD, Franz CE, Azari $R$, Wilkes MS, et al.: Influence of patients' requests for direct-to-consumer advertised antidepressants: a randomised controlled trial. JAMA 2005; 293: 1995-2002.

5. Parnes B, Smith PC, Gilroy C, Quintela J, Emsermann $C B$, et al.: Lack of impact of direct-toconsumer advertising on the physician-patient 
encounter in primary care: a SNOCAP report. Ann Fam Med 2009; 7: 41-46.

6. Daubresse M, Hutfless S, Kim Y, Kornfield R, Qato $D M$, Huang J, et al.: Effect of Direct-to-Consumer Advertising on Asthma Medication Sales and Healthcare Use. Am J Respir Crit Care Med 2015; 192: 40-46.

7. Mintzes B, Barer ML, Kravitz RL, Kazanjian A, Bassett K, Lexchin $J$, et al.: Influence of direct to consumer pharmaceutical advertising and patients' requests on prescribing decisions: two site cross sectional survey. BMJ 2002; 324: 278-279.

8. Basara LR: The impact of a direct-to-consumer prescription medication advertising campaign on new prescription volume. Drug Inf J 1996; 30: 715 729.

9. McAfee T, Davis KC, Shafer P, Patel D, Alexander $R$, Bunnell $R$, et al.: Increasing the dose of television advertising in a national antismoking media campaign: results from a randomised field trial. Tob Control 2015, pii: tobaccocontrol-2015-052517. doi: 10.1136/tobaccocontrol-2015-052517.

10. Hanewinkel R, Isensee B, Sargent JD, Morgenstern $M$ : Cigarette advertising and teen smoking initiation. Pediatrics 2011; 127: e271-278.

11. Duke JC, Nonnemaker JM, Davis KC, Watson KA, Farrelly $M C$ : The impact of cessation media messages on cessation-related outcomes: results from a national experiment of smokers. Am J Health Promot 2014; 28: 242-250.

12. Popova L, Neilands TB, Ling PM: Testing messages to reduce smokers' openness to using novel smokeless tobacco products. Tob Control 2014; 23: 313-321.

13. Mudde AN, DeVries H: The reach and effectiveness of a national mass media-led smoking cessation campaign in The Netherlands. Am J Public Health 1999; 89: 346-350.

14. Sutfin EL, Szykman LR, Moore MC: Adolescents' responses to anti-tobacco advertising: exploring the role of adolescents' smoking status and advertisement theme. J Health Commun 2008; 13: 480-500.

15. Bauman AE, Bellew B, Owen N, Vita $P$ : Impact of an Australian Mass Media Campaign Targeting Physical Activity in 1998. Am J Prev Med 2001; 21: 41-47.

16. Wimbush E, MacGregor A, Fraser E: The effects of a national mass media campaign on walking in Scotland. Health Prom Int 1998; 13: 45-53.

17. Young DR, Haskell WL, Taylor CB, Fortmann SP: Effect of community health education on physical activity knowledge, attitudes, and behaviour. Am J Epidemiol 1996; 144: 264-274.

18. Booth M, Bauman A, Oldenburg B, Owen $N$, Magnus $P$ : Effects of a national mass-media campaign on physical activity participation. Health Promot Int 1992; 7: 241-247.

19. Owen N, Bauman A, Booth $M$, Oldenburg $B$, Magnus P: Serial mass-media campaigns to promote physical activity: reinforcing or redundant? Am J Public Health 1995; 85: 244-248.

20. Williams DM, Matthews Ch, Rutt C, Napolitano $M A$, Marcus $B H$ : Interventions to Increase Walking Behavior. Med Sci Sports Exerc 2008; 40, (7 Suppl): S567-S573.

21. Huhman M, Potter LD, Wong FL, Banspach SW, Duke JC, Heitzler CD: Effects of a Mass Media campaign to increase physical activity among children: year-1 results of the VERB campaign. Pediatrics 2005; 116: e277-84.

22.Berry TR, Craig CL, Faulkner G, Latimer A, Rhodes $R$, Spence JC, et al.: Mothers' intentions to support children's physical activity related to attention and implicit agreement with advertisements. Int J Behav Med 2014; 21: 131-138.

23. Berry TR, Shields $C$ : Source attribution and credibility of health and appearance exercise advertisements: relationship with implicit and explicit attitudes and intentions. J Health Psychol 2014; 19: 242252.

24. Reger B, Cooper L, Booth-Butterfield S, Smith H, Bauman A, Wootan $M$, et al.: Wheeling Walks: a community campaign using paid media to encourage walking among sedentary older adults. Prev Med 2002; 35: 285-292.

25. Hillsdon M, Cavill N, Nanchahal K, Diamond A, White $R$ : National level promotion of physical activity: results from England's ACTIVE for LIFE campaign. J Epidemiol Commun Health 2001; 55: 755-761.

26. Wong F, Huhman $M$, Heitzler C, Asbury L, Bretthauer-Mueller R, McCarthy S, et al.: VERB: a social marketing campaign to increase physical activity among youth. Prev Chronic Dis 2004; 1: A10. Epub 2004 Jun 15.

27. Marcus BH, Owen N, Forsyth LH, Cavill NA, Fridinger $F$ : Interventions to promote physical activity using mass media, print media and information technology. Am J Prev Med 1998; 15: 362378 .

28. Berry TR, Shields C: Source attribution and credibility of health and appearance exercise advertisements: relationship with implicit and explicit attitu- 
des and intentions. J Health Psychol 2014; 19: 242252.

29. Berry TR, Craig CL, Faulkner G, Latimer A, Rhodes R, Spence JC, et al.: Mothers' intentions to support children's physical activity related to attention and implicit agreement with advertisements. Int J Behav Med 2014; 21: 131-138.

30. Bauman AE, Bellew B, Owen N, Vita P: Impact of an Australian mass media campaign targeting physical activity in 1998. Am J Prev Med 2001; 21: 4147.

31. Ostbye T, Pomerleau J, White M, Coolich M, McWhinney J: Food and nutrition in Canadian "prime time" television commercials. Can J Public Health 1993; 84: 370-374.

32. Romero-Fernández MM, Royo-Bordonada MÁ, Rodriguez-Artalejo F: Evaluation of food and beverage television advertising during children's viewing time in Spain using the UK nutrient profile model. Public Health 2013; 16: 1314-1320.

33. Effertz T, Wilcke AC: Do television food commercials target children in Germany? Public Health Nutr 2012; 15: 1466-1473.

34. Coon KA, Tucker KL: Television and children's consumption patterns. A review of the literature. Minerva Pediatr 2002; 54: 423-436.

35. Utter J, Scragg R, Schaaf D: Associations between television viewing and consumption of commonly advertised foods among New Zealand children and young adolescents. Public Health Nutr 2006; 9: 606-612.

36. Boyland EJ, Kavanagh-Safran M, Halford JC: Exposure to 'healthy' fast food meal bundles in television advertisements promotes liking for fast food but not healthier choices in children. Br J Nutr 2015; 113: 1012-1018.

37. Hastings $G$, Stead M, McDermott L, Forsyth A, Mackintosh AM, Rayner $M$, et al.: Review of Research on the Effects of Food Promotion to Children. Glasgow: University of Strathclyde Centre for Social Medicine; 2003.

38. Cairns G, Angus K, Hastings G: The Extent, Nature and Effects of Food Promotion to Children: A Review of the Evidence to December 2008. Geneva: World Health Organization Press; 2009.

39. Kunkel D, Wilcox BL, Cantor J, et al. (2004) Report of the APA task force on advertising and children. Available at: https: //www.apa.org/pi/families/resources/advertising-children.pdf, dostęp: 15.12.2015

40. Institute of Medicine: Food Marketing to Children and Youth: Threat or Opportunity? Washington, DC: The National Academies Press; 2006.
41. Story M, French $S$ : Food advertising and marketing directed at children and adolescents in the US. Int $\mathrm{J}$ Behav Nutr Phys Act 2004; 1: 3.

42. Effertz T, Wilcke AC: Do television food commercials target children in Germany? Public Health Nutr 2012; 15: 1466-1473.

43. Zimmerman FJ, Bell JF: Associations of television content type and obesity in children. Am J Public Health 2010; 100: 334-340.

44. Chronic Diseases and Health Promotion. Reducing the Marketing of Unhealthy Foods to Children. Geneva: WHO; 2011. Available at: http: //www. who.int/chp/media/news/releases/2011_1_marketing/en

45. A Spoonful of Sugar: Television food advertising aimed at children, an international comparative survey. London: Consumers International Prog; 1996.

46. Verri AP, Verticale MS, Vallero E, Bellone S, Nespoli $L$ : Television and eating disorders. Study of adolescent eating behavior. Minerva Pediatr 1997; 49: 235-243.

47. Lobstein T, Dibb S: Evidence of a possible link between obesogenic food advertising and child overweight. Obes Rev 2005; 6: 203-208.

48. Carter $O B$ : The weighty issue of Australian television food advertising and childhood obesity. Health Promot J Austr 2006; 17: 5-11.

49. Gortmaker SL, Must A, Sobol AM, Peterson K, Colditz GA, Dietz WH: Television viewing as a cause of increasing obesity among children in the United States, 1986-90. Arch Pediatr Adolesc Med 1996; 150: 356-362.

50. Robinson TN: Reducing children's television viewing to prevent obesity: a randomized controlled trial. JAMA 1999; 282: 1561-1567.

51. Kaiser Family Foundation: The Role of Media in Childhood Obesity. Available at: http: //kaiserfamilyfoundation.files.wordpress.com/2013/01/the-role-of-media-in-childhood-obesity.pdf

52. Halford JC, Gillespie J, Brown V, Pontin EE, Dovey $T M$ : Effect of television advertisements for foods on food consumption in children. Appetite 2004; 42: 221-225.

53. Childhood Obesity - Food Advertising in Context. Available at: http: //stakeholders.ofcom.org.uk/binaries/research/tv-research/report2.pdf, dostęp

54.Lawlor DA, Benfield L, Logue J, Tilling K, Howe $L D$, Fraser A, et al.: Association between general and central adiposity in childhood, and change in these, with cardiovascular risk factors in adolescence: prospective cohort study. BMJ 2010; 341: 
c6224. doi: 10.1136/bmj.c6224.

55. Romero-Fernández MM, Royo-Bordonada MÁ, Rodríguez-Artalejo F: Evaluation of food and beverage television advertising during children's viewing time in Spain using the UK nutrient profile model. Public Health Nutr 2013; 16: 1314-1320.

56. Hargreaves D, Tiggemann M: The Effect Of Television Commercials On Mood And Body Dissatisfaction: The Role Of Appearance-Schema Activation. J Social Clin Psychol 2002; 21: 287308.

57. WHO: Health Impact Assessment Promoting health across all sectors of activity. Available at: http: //www.who.int/hia/en/

58. Włodarczyk C: Koncepcja „Oceny wpływu na zdrowie" (Health Impact Assessment) i jej wykorzystywanie w Unii Europejskiej. Perspektywa sektora prywatnego. Zesz Nauk Ochr Zdr Zdr Pub Zarz 2010; 8: 79-94.

59. The Effectiveness of Health Impact Assessment. Available at: http: //www.euro.who.int/_data/ assets/pdf_file/0003/98283/E90794.pdf, dostęp: 23.12.2015.

60. Altkorn J: Podstawy marketingu. Kraków: Instytut Marketingu; 2001.

61. Nowotarska-Romaniak B: Marketing usług zdrowotnych - koncepcje i stosowanie. Kraków: Wolter Kluwers Polska; 2013.

62. Kotler P: Marketing: analiza, planowanie, wdrażanie i kontrola. Warszawa: Wydawnictwo Gebethner\&Spółka; 1994.

63. Lambin JJ: Strategiczne zarządzanie marketingowe. Warszawa: Wydawnictwo Naukowe PWN; 2001.

64. Bukowska-Piestrzyńska A: Marketing usług zdrowotnych - od budowania wizerunku placówki do zadowolenia klienta. Warszawa: Wydawnictwo CeDeWu; 2012.

65. Tajniki marketingu - przewodnik po marketingu dla studentów MBA.Warszawa: Liber; 2002.

66. Cheverton P: Zarządzanie kluczowymi klientami. Kraków: ABC Dom Wydawniczy; 2001.

67. Kotler P, Shalowitz J, Stevens RJ: Marketing strategiczny w opiece zdrowotnej. Warszawa: Wolter Kluwer Polska; 2013. p.504-574.

68. Kurzeja E: Reklama Perswazja w telewizyjnej reklamie społecznej (praca doktorska). Katowice: Uniwersytet Śląski w Katowicach; 2014. Available at: http: //docplayer.pl/1651630-Perswazjaw-telewizyjnej-reklamie-spolecznej-studiumsocjologiczne.html.
69. Paszkiewicz A: Wpływ reklamy telewizyjnej na dzieci, Available at: http: //eetp.ignatianum.edu. pl/sites/eetp/files/artykuly/eetp.19-art.paszkiewicz. pdf

70. Stolarska A: Wpływ reklamy społecznej na postawy i zachowania odbiorców przekazu. Available at: https: //tnkul.pl/files/userfiles/files/ REiZ_2012_4\%2840\%29_309-325_Stolarska.pdf, dostęp:

71. Maison D, Wasilewski P, editors: Propaganda dobrych serc czyli pierwszy tom o reklamie społecznej. Kraków: Wydawca Agencja Wasilewski; 2008. p.128-132.

72. Rogala M: Obszar badawczy HIA: Wpływ reklamy telewizyjnej na zdrowie. Raport nt. Badanie perspektyw zastosowania w Polsce metodologii Oceny Skutku Zdrowotnego (Health Impact Assessment, HIA) - w ramach projektu „Ograniczanie społecznych nierówności w zdrowiu", Programu PL 13 współfinansowanego ze środków Norweskiego Mechanizmu Finansowego 2009-2014 - w ramach konsorcjum „Nauka i Zdrowie (umowa nr A-AE$\mathrm{KN}-12 / 5 / 2013)$.

73. Jerzy Owsiak tęczowo reklamuje WOŚP z Play także w krytykującej go Telewizji Republika. Available at: http: //www.wirtualnemedia.pl/artykul/jerzy-owsiak-teczowo-reklamuje-wosp-zplay-takze-w-krytykujacej-go-telewizji-republikawideo

74. Kampaniespoleczne.pl: $Z$ fotela się rusz, ale już. Available at: http: //www.kampaniespoleczne.pl/ kampanie, 571, z_fotela_sie_rusz_ale_juz, dostęp: 31.12.2015.

75. Cobiac L, Vos T, Doran C, Wallace A: Costeffectiveness of interventions to prevent alcohol-related disease and injury in Australia. Addiction 2009; 104: 1646-1655.

76. Sanecka E: Manipulacja w reklamie telewizyjnej skierowanej do dzieci Available at: http: // www.kmt.uksw.edu.pl/media/pdf/kmt_2013_13_ Sanecka.pdf

77. Nowakowski PT: Fast food dla mózgu, czyli telewizja i okolice. Tychy: Maternus Media; 2002.p.23.

78. Sanecka E: Psychologiczne mechanizmy oddziaływania reklamy a manipulacja w reklamie. Available at: http: //www.publikacje.edu.pl/pdf/10023.pdf

79. Antosik M: Człowiek współczesny w obliczu manipulacji. Available at: http: //www.kwartalnik.wsiie. olsztyn.pl/sites/default/files/kwartalnik/2014/1/ Kwartalnik1_2014_4.pdf

80. Maison D., Wasilewski P, editors: Propaganda dobrych serc czyli pierwszy tom o reklamie społecz- 
nej. Kraków: Agencja Wasilewski; 2008. p.9-41.

81. Impact of media use on children and youth. Paediatr Child Health 2003; 8: 301-306.

82. Children, adolescents, and advertising. Committee on Communications, American Academy of Pediatrics. Pediatrics 2006; 118: 2563 -2569.

83. Lekarze w reklamach - komunikat Naczelnego Rzecznika Odpowiedzialności Zawodowej. Available at: http: //www.nil.org.pl/aktualnosci/ lekarze-w-reklamach-komunikat-naczelnegorzecznika-odpowiedzialnosci-zawodowej

Address: 31 -531 Kraków, ul. Grzegórzecka 20

Tel.: +4812 4332813

e-mail: maciej.rogala@uj.edu.pl

Received: $31^{\text {st }}$ January 2016

Accepted: 24th April 2016 